\title{
Dutch translation of the fear of pain questionnaire: Factor structure, reliability and validity: a comment on
}

Citation for published version (APA):

Roelofs, J., Peters, M. L., \& Vlaeyen, J. W. S. (2007). Dutch translation of the fear of pain questionnaire: Factor structure, reliability and validity: a comment on. European Journal of Pain, 11(1), 121-122. https://doi.org/10.1016/j.ejpain.2006.08.002

Document status and date:

Published: 01/01/2007

DOI:

10.1016/j.ejpain.2006.08.002

Document Version:

Publisher's PDF, also known as Version of record

Document license:

Taverne

Please check the document version of this publication:

- A submitted manuscript is the version of the article upon submission and before peer-review. There can be important differences between the submitted version and the official published version of record.

People interested in the research are advised to contact the author for the final version of the publication, or visit the DOI to the publisher's website.

- The final author version and the galley proof are versions of the publication after peer review.

- The final published version features the final layout of the paper including the volume, issue and page numbers.

Link to publication

\footnotetext{
General rights rights.

- You may freely distribute the URL identifying the publication in the public portal. please follow below link for the End User Agreement:

www.umlib.nl/taverne-license

Take down policy

If you believe that this document breaches copyright please contact us at:

repository@maastrichtuniversity.nl

providing details and we will investigate your claim.
}

Copyright and moral rights for the publications made accessible in the public portal are retained by the authors and/or other copyright owners and it is a condition of accessing publications that users recognise and abide by the legal requirements associated with these

- Users may download and print one copy of any publication from the public portal for the purpose of private study or research.

- You may not further distribute the material or use it for any profit-making activity or commercial gain

If the publication is distributed under the terms of Article $25 \mathrm{fa}$ of the Dutch Copyright Act, indicated by the "Taverne" license above, 


\title{
Dutch translation of the fear of pain questionnaire: Factor structure, reliability and validity: A comment on van Wijk and Hoogstraten (2006)
}

\author{
Jeffrey Roelofs *, Madelon L. Peters, Johan W.S. Vlaeyen \\ Department of Medical, Clinical and Experimental Psychology, Maastricht University, P.O. Box 616, Maastricht, 6200 MD, The Netherlands
}

Received 20 July 2006; accepted 10 August 2006

Available online 2 October 2006

We read with great interest a recent paper by van Wijk and Hoogstraten (2006), which examined psychometric properties of a Dutch translation of the fear of pain questionnaire (FPQ). The authors used a sophisticated and systematic approach to evaluate their model. More specifically, confirmatory factor analysis was used to assess the fit of a one-factor and a three-factor model of the FPQ, and then to examine the construct validity. Reliability in terms of internal consistency and testretest stability was also assessed. In this letter, we would like to take this opportunity to briefly integrate the major findings of both this study and our own study on the psychometric properties of a Dutch version of the FPQ (Roelofs et al., 2005), and to provide directions for future research.

Both studies attempted to address the factor structure of the FPQ by means of confirmatory factor analysis. Although a three-factor model of the FPQ comprising fear related to severe pain, minor pain, and medical pain, proved to have the best fit compared to the competing models, the fit indices of this model did not meet the predefined criteria in both studies. There are two explanations that warrant consideration. First, the fit of a model can be affected by violations of assumptions (on which maximum likelihood estimation techniques are based), such as multivariate normality, and by a low variable to sample size ratio. van Wijk and Hoogstraten (2006) used item parceling, which involves sum-

\footnotetext{
* Corresponding author. Tel.: +31 43 3881607; fax: +31433884155 . E-mail address: J.Roelofs@dep.unimaas.nl (J. Roelofs).
}

ming or averaging item scores from two or more items and using these parcel scores instead of the separate item scores in the confirmatory factor analysis. By doing item parceling, item distributions become more continuous and normally distributed and a more optimal variable to sample size ratio is obtained, leading to more stable parameter estimates and subsequently to a better fit. Although the fit of the model did increase substantially after item parceling, the fit indices were still unsatisfactory (see van Wijk and Hoogstraten, 2006).

Second, it is possible that the three-factor model of the FPQ tested in both studies is not the best model in its present form, leaving room for improvements. In this light, it is interesting to note that the results from both studies suggested several improvements of the model that could be made to obtain a satisfactory fit. Particularly interesting is the presence of four items in the medical pain scale that refer to 'needle' or 'injection'. On the basis of their residual correlations, we have suggested that these items may form an 'injection' scale within the medical pain scale. This 'injection' scale may reflect a specific aspect of pain-related fear but may also be indicative of a fear towards bloodinjection. There were also some items with strong residual correlation that might be redundant. For example, the items 'breaking a leg' and 'breaking an arm' are quite similar in content and perhaps just one of these items will be sufficient. It should be borne in mind that the best way to evaluate models is to formulate competing models and test them against each other. We tested a three-factor model that included an 'injection' scale and allowed some items to have residual 
correlation. These changes to the model resulted in an adequate fit (see Roelofs et al., 2005). Taken together, the results from both studies clearly suggest that the FPQ should be further refined.

Both studies provided support for the construct validity of the FPQ scales. That is, the FPQ scales were convincingly associated with measures of pain-related fear (Roelofs et al., 2005) and fear related to dentistry (van Wijk and Hoogstraten, 2006). Modest links were found between the FPQ scales and negative affect such as trait anxiety and depression in both studies. No substantial associations were found between the FPQ scales and specific fears such as fear of spiders (Roelofs et al., 2005) and fear of computers (van Wijk and Hoogstraten, 2006). It is noteworthy to mention that we also found evidence for the predictive validity of the FPQ and its scales. More specifically, scores on the FPQ and its scales were predictive of fear associated with undergoing three different experimental pain tests (see Roelofs et al., 2005). With respect to reliability, internal consistency ratings were good and quite comparable across both studies. Test-retest stability was reasonable (van Wijk and Hoogstraten, 2006).

In sum, it is clear that both studies complement each other in terms of evidence for psychometric properties of the FPQ. Future research on the FPQ should be focused on further refining the factor structure as well as the reliability and validity of this instrument. Some attempts have been made in that direction. For example, Albaret et al. (2004) have produced a reduced 15-item version of the FPQ that seemed a viable alternative to the original version. Kennedy et al. (2001) developed a 9-item version of the FPQ. It would also be interesting to test the various models against each other by means of confirmatory factor analysis and then re-assess reliability and validity of the model with best fit in clinical and non-clinical samples. Moreover, the relative contribution of the FPQ and its scales beyond other measures of pain-related fear should be assessed in future research. This research may contribute to an increase of our knowledge and understanding of pain-related fear in clinical and non-clinical samples.

\section{References}

Albaret MC, Sastre MTM, Cottencin A, Mullet E. The Fear of Pain Questionnaire: factor structure in samples of young, middle-aged an elderly European people. Eur J Pain 2004;8:273-81.

Kennedy SG, McNeil DW, Hursey KG, Vowles KE, Sorrell JT, Lawrence SM, et al. Development of a short form of the fear of pain questionnaire. In: Poster presented at the meeting of the association for the advancement of behavior therapy, Philadelphia, PA, 2001.

Roelofs J, Peters ML, Deutz J, Spijker C, Vlaeyen JWS. The Fear of Pain Questionnaire (FPQ): further psychometric examination in a non-clinical sample. Pain 2005;116:339-46.

van Wijk AJ, Hoogstraten J. Dutch translation of the Fear of Pain Questionnaire: factor structure, reliability and validity. Eur J Pain 2006;10:479-86. 